\title{
Epilepsie en het hart: hoe kunnen we SUDEP beter begrijpen en voorkomen?
}

Op I6 oktober 2019 promoveerde Marije van der Lende aan de Universiteit Leiden op haar proefschrift getiteld 'Epilepsy and cardiac arrhythmias: understanding and preventing SUDEP'. Van der Lende toont aan dat screening naar postictale ritmestoornissen bij hoog risico-groepen niet effectief is, maar dat het optimaliseren van het nachtelijk toezicht wel een effectief middel is om de kans op overlijden te verminderen.

Sudden Unexpected Death in Epilepsy (SUDEP) is een ingrijpende complicatie van epilepsie en de meest voorkomende epilepsie-gerelateerde doodsoorzaak. Naarmate de ernst van de epilepsie toeneemt, neemt ook de incidentie toe. Er zijn geen gerichte maatregelen om SUDEP te voorkomen. Er zijn enkele aanwijzingen dat nachtelijk toezicht helpt maar de bewijsvoering hiervoor is te mager. De beste manier om het risico op SUDEP te verlagen is het verminderen van het aantal aanvallen, in het bijzonder tonischclonische aanvallen (Harden et al., 2017). Van der Lende richtte haar onderzoek op twee pijlers: het screenen naar ritmestoornissen bij hoog risico-patiënten en de potentie van nachtelijk toezicht om het SUDEP-risico te verlagen.

\section{Ictale versus postictale asystolie}

Het proefschrift begint met een systematisch literatuuronderzoek naar hartritmestoornissen bij epilepsie (Van der Lende et al., 20r6a). De meest voorkomende ritmestoornis bleek de ictale asystolie. Deze ritmestoornis deed zich uitsluitend voor bij focale aanvallen met verminderde gewaarwording en was nooit fataal. Dit leverde een duidelijk contrast op met de postictale ritmestoornissen (asystolie of ventrikelfibrilleren): deze waren wel geassocieerd met SUDEP en werden altijd voorafgegaan door een tonischclonische aanval. De contrasterende klinische profielen wijzen op verschillende pathomechanismen. Van der Lende postuleert dat ictale asystolieën niet dodelijk zijn, doordat de ictale asystolie via een circulatiestilstand de ictale corticale activiteit opheft waardoor het focale insult dat de asystolie veroorzaakt, stopt.

\section{Screening niet effectief}

Postictale ritmestoornissen zijn weliswaar sterk gekoppeld aan SUDEP maar screening naar deze ritmestoornissen bij hoog-risico groepen blijkt niet effectief te zijn. Deze bevindingen vormden de opmaat voor een grote prospectieve trial naar de opbrengst van lange termijn ECG-registraties (van der Lende, in press). Bij 49 mensen met refractaire focale epilepsie werd een implanteerbare hartritmemonitor geplaatst en werd het hartritme twee jaar lang gevolgd. Er werden in totaal 16.474 aanvallen gerapporteerd. Er werden geen potentieel fatale hartritmestoornissen gevonden, met name geen postictale hartritmestoornissen die als potentiele SUDEP-biomarkers zouden kunnen dienen, ondanks de meer dan $\mathrm{r} 6.000$ epileptische aanvallen gedurende de lange termijn follow up. Bij drie personen werden klinisch niet relevante asystolieën $(<4 \mathrm{~s})$ gevonden. Geen van deze asystolieën was gerelateerd aan een epileptische aanval. Het onderzoek toont dat lange termijn-registraties van het hartritme bij mensen met refractaire focale epilepsie niet effectief zijn om vroegtijdig hoog risico-patiënten te identificeren.

\section{Hoe minder toezicht, hoe meer gemiste aanvallen} Het tweede deel van het proefschrift richt zich op de rol van bewaking. Naar aanleiding van een plotseling overlijden werd bij Stichting Epilepsie Instellingen Nederland (SEIN) mede op advies van de Inspectie voor de Gezondheidszorg de nachtelijke videomonitoring uitgebreid. Van der Lende greep deze situatie aan om de toegevoegde waarde van videomonitoring te onderzoeken (Van der Lende et al., 20I6b). Alle 4I patiënten met epilepsie waarbij het nachtelijk toezicht (akoestische bewaking al dan niet aangevuld met een matrassensor) werd uitgebreid met videomonitoring, werden gedurende zes maanden gevolgd. In totaal werden I.208 aanvallen gerapporteerd. 
Videomonitoring bleek de detectie van nachtelijke aanvallen te verhogen: $33 \%$ van alle aanvallen was alleen op video te zien. Dit betrof echter vooral aanvallen zonder klinische relevantie vanuit het SUDEP-perspectief: tonische in plaats van tonisch-clonische aanvallen en aanvallen waar geen interventie voor nodig is. Er werden dankzij videobewaking ook aanvallen gezien waar wel interventie nodig was, maar dit aantal was klein (39 van de 1207 aanvallen). De keerzijde van videomonitoring is dat het nadelig is voor de privacy en erg duur: de personeelskosten werden geschat op $€ 7.035$ per aanval, die alleen werd gezien op video en waarbij een interventie gedaan werd. Het wordt daarom niet aanbevolen om videomonitoring op grote schaal in te zetten op alle woonvoorzieningen voor mensen met epilepsie met een hoog risico op SUDEP. Het onderzoek onderstreept wel het belang van de ontwikkeling van efficiënte hulpmiddelen om aanvallen te detecteren.

\section{Hoe minder toezicht, hoe groter het SUDEP-risico} In haar laatste onderzoek gaat Van der Lende dieper in op het potentiële beschermende effect van nachtelijke bewaking op het SUDEP-risico. Hiertoe heeft ze alle overlijdens bestudeerd van de afgelopen 25 jaar in twee woonzorginstellingen voor mensen met epilepsie en een verstandelijke beperking: SEIN, locatie de Cruquiushoeve, Nederland en Chalfont Centre for Epilepsy, Chalfont St Peter, Verenigd Koninkrijk. Er werden 6o SUDEP-cases geïdentificeerd, die gematched werden met 198 controles. De incidentiecijfers van beide centra bleken significant verschillend: 2,2I/I.000 persoonsjaren ( $95 \%$ betrouwbaarheidsinterval I, 49-3,27) in SEIN versus 6,I2/I.0oo persoonsjaren ( $95 \%$ betrouwbaarheidsinterval $4,40-8,52)$ in Chalfont. Dit verschil kon niet worden verklaard door de ernst van de epilepsie. Daarentegen werd er wel een significant verschil gezien in de mate van toezicht: het centrum met het minste toezicht had de hoogste SUDEP-incidentie (Van der Lende et al., 20I8). Het contrast in nachtelijk toezicht tussen beide centra lijkt grotendeels verklaard te worden door de implementatie van een akoestisch waaksysteem in één van de centra.

\section{Praktische implicaties}

Nachtelijke aanvallen worden vaak gemist en soms betreffen het ook potentieel gevaarlijke aanvallen. Het beter detecteren van deze aanvallen blijkt het SUDEP-risico te verlagen. Toekomstig onderzoek moet verder uitwijzen welke hulpmiddelen het beste ingezet kunnen worden en welke patiënten het meest gebaat zijn bij deze interventie. De timing blijkt cruciaal bij het beoordelen van ritmestoornissen bij aanvallen. Het is niet nuttig om (zonder directe klinische aanleiding) langdurige ECG-registraties in te zetten bij patiënten met een hoog SUDEP-risico. Voor het ontwikkelen van een effectievere screening is een andere insteek noodzakelijk. Hierbij kan gedacht worden aan het gebruik van een andere modaliteit (bijvoorbeeld elektrodermale activiteit), een andere ECG-parameter (bijvoorbeeld hartritmevariabiliteit) of aan het combineren van modaliteiten.

\section{Referenties}

Harden Tomson T, Gloss D et al. (2017) Practice guideline summary: Sudden unexpected death in epilepsy incidence rates and risk factors: Report of the Guideline Development, Dissemination, and Implementation Subcommittee of the American Academy of Neurology and the American Epilepsy Society. Neurology 88:1674-1680.

Van der Lende M, Arends JB, Lamberts RJ et al. (2019) The yield of long term ECG recordings in refractory focal epilepsy. Epilepsia, in press.

Van der Lende M, Cox FM, Visser GH et al. (20r6a) Value

of video monitoring for nocturnal seizure detection in a residential setting. Epilepsia 57:1748-1753.

Van der Lende M, Hesdorffer DC, Sander JW et al. (2018)

Nocturnal supervision and SUDEP risk at different

epilepsy care settings. Neurology 91:e1508-e1518.

Van der Lende M, Surges R, Sander JW et al. (2016b)

Cardiac arrhythmias during or after epileptic seizures. J Neurol Neurosurg Psychiatry 87(1):69-74.

\section{Lees het actuele overzicht van} congressen over epilepsie.

\section{Kijk voor meer informatie op www.epilepsieliga.nl.}

